\title{
Primary health care nurses: attitudes towards the person with mental disorder
}

\author{
Enfermeiros de atenção primária à saúde: atitudes frente à pessoa com transtorno mental
}

Enfermeras de atención primaria: actitudes frente a la persona con trastorno mental

\author{
Maria do Perpétuo Socorro de Sousa Nóbrega ${ }^{a}$ \\ Carla Sílvia Neves da Nova Fernandes ${ }^{b}$ \\ Sonia Regina Zerbettoc \\ Francisco Miguel Correia Sampaio ${ }^{d}$ \\ José Carlos Carvalhob \\ Suellen Cristina da Silva Chaves ${ }^{\mathrm{a}}$
}

How to cite this article: Nóbrega MPSS, Fernandes CSNN, Zerbetto SR, Sampaio FMC, Carvalho JC, Chaves SCS. Primary health care nurses: attitudes towards the person with mental disorder. Rev Gaúcha Enferm. 2021;42:e20200088. doi: https://doi.org/10.1590/19831447.2021.20200088
Universidade de São Paulo (USP), Escola de Enfermagem. São Paulo, São Paulo, Brasil.

${ }^{\mathrm{b}}$ Escola Superior de Enfermagem do Porto (ESEP). Porto, Portugal.

"Universidade Federal de São Carlos (UFSCar). São Carlos, São Paulo, Brasil.

¿ Universidade Fernando Pessoa (UFP). Porto Portugal.

\section{ABSTRACT}

Objective: To identify the attitudes of nurses working in Primary Health Care towards the person with mental disorder and the variables related to health care provided.

Methodology: Descriptive, correlational study with 250 nurses from 69 Basic Health Units in the city of São Paulo. Data collection took place between April and August 2019 using the "Opinions about Mental IIIness" scale. The data were analyzed using the KrusKalWallis test, with a 95\% confidence level and statistical significance of $p<0.05$.

Results: The global mean of the scale was 197, which shows negative attitudes especially in the dimensions of Authoritarianism (44.6), Social Restriction (42.0), and positive in the dimension of Benevolence (51.7).

Conclusion: Nurses tend to have a stigmatizing attitudinal profile. It is necessary formative and permanent intervention so that it is possible to reduce stigma and improve community-based care recommended in the guidelines of the Psychosocial Care Network. Keywords: Mental health assistance. Mental health. Attitude of health personnel. Primary nursing.

\section{RESUMO}

Objetivo: Identificar as atitudes dos enfermeiros que atuam na Atenção Primária à Saúde frente à pessoa com transtorno mental e as variáveis relacionados aos cuidados de saúde prestados.

Metodologia: Estudo descritivo, correlacional, com 250 enfermeiros de 69 Unidades Básica de Saúde do município de São Paulo, A coleta de dados ocorreu entre abril e agosto de 2019 por meio da escala "Opiniões acerca da Doença Mental". Os dados foram analisados por meio do teste de KrusKal-Wallis, com nível de confiança de 95\% e significância estatística de $p<0,05$.

Resultados: A média global da escala foi 197, que demonstra atitudes negativas especialmente nas dimensões de Autoritarismo $(44,6)$, Restrição Social $(42,0)$, e positiva na dimensão Benevolência $(51,7)$.

Conclusão: Os enfermeiros apresentam, tendencialmente, perfil atitudinal estigmatizante. É necessária intervenção formativa e permanente para que seja possível reduzir o estigma e melhorar o cuidado de base comunitária preconizado nas diretrizes da Rede de Atenção Psicossocial.

Palavras-chave: Assistência à saúde mental. Saúde mental. Atitude do pessoal de saúde. Enfermagem primária.

\section{RESUMEN}

Objetivo: Identificar las actitudes de los enfermeros que trabajan en Atención Primaria de Salud frente a la persona con trastorno mental y las variables relacionadas con la atención médica brindada.

Metodología: Estudio descriptivo, correlacional con 250 enfermeras de 69 Unidades Básicas de Salud en la ciudad de São Paulo. La recopilación de datos tuvo lugar entre abril y agosto de 2019 utilizando la escala "Opiniones sobre enfermedades mentales". Los datos se analizaron mediante la prueba de KrusKal-Wallis, con un nivel de confianza del $95 \%$ y una significación estadística de $p<0,05$.

Resultados: El promedio global de la escala fue 197, lo que muestra actitudes negativas especialmente en las dimensiones de Autoritarismo (44.6), Restricción social (42.0), y positivas en la dimensión de Benevolencia (51.7).

Conclusión: Las enfermeras tienden a tener un perfil de actitud estigmatizante. La intervención formativa y permanente es necesaria para que sea posible reducir el estigma y mejorar la atención comunitaria recomendada en las pautas de la Red de Atención Psicosocial. Palabras clave: Atención a la salud mental. Salud mental. Actitud del personal de salud. Enfermería primaria. 


\section{口INTRODUCTION}

Since the 1970s, that in Brazil, the mental health field has been fighting for better conditions of assistance for people with mental disorders (MD). Throughout this process of reformulation of psychiatric assistance, the approval of Law No. 10.216/2001 of the National Mental Health Policy, guidelines were outlining actions with a view to deconstructing a model based on the control and surveillance of the person with/in mental suffering, for a proposition of inclusive care and in freedom.

Along this path, in 2011, it was established by the Ordinance 3.088 the Psychosocial Care Network (PSCN), with a view to creating and expanding the population's means of access to territorial-based psychosocial assistance. As one of the components of the PSCN, Primary Health Care (PHC) is configured as an investment locus for mental health, since it has the role of articulating the itinerary and flow of users with the various points of the network, as well as leading mental health actions in this sphere.

However, it is observed in practice that the conceptions of PHC professionals, namely, nurses in relation to mental health care and the mental health-disease process are antagonistic: on the one hand, they are concerned with the incorporation of the psychiatric reform precepts in the assistance, on the other hand, have difficulties to distance themselves from the psychopathologization and medicalization of suffering verbalized by the subject, and that the satisfactory outcomes of actions of attention and promotion of mental health are related to the lack of training, updates, stigma and prejudice in relation to madness, which compromise a praxis directed to the psychosocial aspect ${ }^{(1)}$.

Since nurses represent the largest contingent of PHC workers, it is essential that they are prepared and encouraged to have attitudes that lead them to take responsibility for the offer of singular, resolute and effective mental health care in the context of the PSCN and contribute to advance in a movement of strengthening and articulation between these two fields. Attitudes are convictions and feelings that predispose individuals to have reactions to objects, people, events. When considering that someone is a bad person and has a bad character, individuals can nurture attitudes of repulse and hostility towards that person ${ }^{(2)}$. When attitudes are negative, they promote low self-esteem, social isolation and abandonment of treatment, but when positive, they are less stigmatizing, stimulate bonding, and aggregate mental health users to care services ${ }^{(3-4)}$.

Intercultural study on the attitudes of nurses working in PHC towards people with mental health problems, conducted in five countries on the European continent (Finland,
Lithuania, Ireland, Italy and Portugal), showed that nurses' attitudes were predominantly positive. The attitudes of Portuguese nurses were significantly more positive, and those of Lithuanian nurses, significantly more negative than those of professionals in other countries. The authors point out that attitudes can be affected by social and cultural circumstances, but they are also linked to the attitudes of the general public, that is, the way in which MD are seen in the respective countries, leads to nurses' attitudes ${ }^{(5)}$.

In Africa, the attitudes of PHC nurses were positive, but these professionals had inadequate knowledge to assist people with this clinical condition ${ }^{(6)}$. In China, nurses have negative attitudes towards people with MD, and $72.9 \%$ agreed that these are a burden for their families and society ${ }^{(7)}$. In Brazil, a study conducted with health professionals in services that care for people with MD, including primary care, showed that less favorable attitudes were prevalent; however, it was not possible to obtain the nurses 'opinion objectively since the study sample was made up of health professionals in general, and did not address the specificities of the nurses' attitudes ${ }^{(8)}$, leaving a gap to be investigated.

Thus, this study aims to identify the attitudes of nurses working in Primary Health Care towards the person with mental disorder and the variables related to health care provided.

\section{METHODS}

Quantitative study, cross-sectional, descriptive-correlational, part of the multicenter study "Attitudes in Primary Health Care" conducted between Portugal and Brazil. Conducted using a non-probabilistic, convenience sample of 250 nurses who work in 69 Basic Health Units (BHU), with and without a Family Health Strategy (FHS) team, from eight Health Districts (HD) that are part of the six Regional Health Coordinations (RHC) in the city of São Paulo. The HD were:Vila Maria/Nila Guilherme Microregion, (North), Butantã Microregion (West), Ipiranga District, Jabaquara and Vila Prudente (Southeast), Guaianazes District (East), Campo Limpo District (South) and Sé District (Center).

The research project was presented to $\mathrm{RHC}$ managers and permanent education nurses. Afterwards, in a meeting with UBS coordinators, the researchers resumed the presentation and invited the professionals to participate in the research. At that time, separate envelopes (questionnaires and consent forms) were also delivered to each coordinator and asked to present the proposal and invite nurses from their units to participate in the research. After the established period, the envelopes were collected. 
The collection was carried out between April and August 2019. It was used a self-administered questionnaire, divided into sociodemographic data (age, gender, marital status), academic data (time since graduation, post-graduation, had content/discipline and internship of mental health during formation, type of formation institution), and work data (length of acting the service, workload/work, knowledge about the health needs of the person with MD, experience of care, frequency of encounters with people with MD at work, evaluation of the assistance offered by the service that works).

To examine the attitudes of professionals, it was used the "Opinions about Mental IIIness" scale, translated and validated in Brazi((9) under the title "Escala de Opiniões sobre a Doença mental" (OMI), composed of 51 items, with Likerttype responses, ranging from 1 (strongly agree) to 6 (strongly disagree).

The $\mathrm{OMl}$ is organized and subdivided into 5 dimensions that correspond to 5 attitudes: Authoritarianism (opinion about the person with $\mathrm{MD}$ as belonging to a "lower class of people"); Benevolence (indicates a vision of paternalistic support and protection in relation to people with $\mathrm{MD}$, with a focus on care, personal attention and material comfort); Mental Hygiene Ideology (perception of the person with MD as being similar to a "normal person", capable of performing complex activities); Social Restriction (people with MD are dangerous for society, and should be restricted in some social domains); Interpersonal Etiology (belief that MD is the result of bad interpersonal experiences in childhood).

The positive attitude represents a predisposition to consider the person with MD as a subject of rights and capable of making choices. When nurses have a positive attitude, they tend to conduct the care process favorably. On the contrary, the negative attitude implies restrictive affective reactions, prejudiced towards the person with $M D$, which arouse fear, skepticism towards psychosocial rehabilitation and non-acceptance. When the nurse have a negative attitude, they tend to conduct unfavorably the care process ${ }^{(5)}$.

The minimum amplitude of the $\mathrm{OMI}$ is 51 and the maximum 306 , with a midpoint of $178.5^{(9)}$. The higher the score, the more negative the attitudes are, except in the Benevolence and Mental Hygiene Ideology dimensions. The midpoints of the OMI dimensions are: Benevolence (49), Social Restriction (35), Authoritarianism (38), Mental Hygiene Ideology (31) and Interpersonal Etiology (24)(9).

For data analysis, it was used IBM SPSS version 25. Descriptive statistics used the frequencies calculation and Standard Deviation (SD). Regarding the correlation between the OMI factors and the numerical variables formation time and workload, Spearman's Coefficient was used. To verify the association between the variables type of institution, having received content/discipline and internship during the training, how do they assess the health needs conducted by the service where they work, contact/experience with people with MD, frequency with which they encounter people with MD, evaluation of the assistance provided to the person with MD and the scale factors, KrusKal-Wallis test was used. Statistical significance was set at $p<0.05$ and a $95 \%$ confidence level. The results were systematized in the form of tables for better exposure of the data. The Cronbach's Alpha coefficient obtained with the application of the MDG was 0.74 .

This study was approved by the Research Ethics Committee with Human Beings of a Public University and by the Secretary of Health of the Municipality of São Paulo, statement No.2,384,303, according to Resolution 466/12 of the National Health Council. All participants signed the Free and Informed Consent Form.

\section{RESULTS}

The findings indicate that the majority of nurses working in the Basic Health Units are female (86\%), aged between 23 and 65 years, with an average age of 36.3 years $(S D=7.5)$, and married (57.6\%). In relation to academic variables, nurses tended to have formation between five and ten years (38.9\%), in a private institution (84\%), working in the profession between one and five years (42.4\%), with specialization in diverse areas (84.8\%) and with a workload of 40 hours per week (63\%). They had mental health content/discipline (98.80\%) and had a mental health internship (90.40\%) during graduation.

Participated professionals from HD/RHC North (26.1\%), West (23.7\%), Southeast (23\%), Center (3.5\%), East (5.8\%) and South (17.9\%), with $52 \%$ of the total of these BHU working with FHS. Regarding the experience/contact with people with MD, $94.2 \%$ had or have, and $64.6 \%$ indicated that they deal with these people daily at work.

\section{Nurses' attitudes towards people with mental disorders}

The overall results of the application of the OMI showed an average of 197.0, higher than the midpoint of the scale $(178)^{(13)}$, with a minimum score of 124 and a maximum of 260, and a standard deviation of 17.2. Table 1 shows that when stratifying the $\mathrm{OMI}$, the mean score on the Mental Hygiene Ideology dimension was 28.1, therefore, low in relation to the midpoint (31); in the Authoritarianism dimension, the mean score is 44.6, higher than the midpoint (38); in Social 
Table 1 - Total and dimensions of the OMl, study Attitudes in Primary Health Care, São Paulo, Brazil, 2019

\begin{tabular}{lccc} 
Dimension & Mean & SD & Amplitude \\
Total Scale & 197.0 & 17.2 & $124-260$ \\
Authoritarianism & 44.6 & 6.2 & $23-63$ \\
Benevolence & 51.7 & 5.4 & $31-68$ \\
Mental Hygiene & 28.1 & 4.0 & $18-42$ \\
Social Restriction & 42.0 & 5.1 & $24-55$ \\
Interpersonal Etiology & 30.6 & 4.8 & $15-42$ \\
\hline
\end{tabular}

Source: Research data, 2019.

Restriction the mean score is 42.0 higher than the mean point (35); and in Interpersonal Etiology, the mean score is 30.6 also higher than the midpoint (24). Therefore, the nurses'attitudes towards mental illness tend to be negative. It differs only in the Benevolence dimension with a score of 51.7 , higher than the midpoint (49), which represents a positive attitude towards the person with MD.

\section{Aspects related to health care provided}

It is noteworthy that nurses characterize as very adequate (31.6\%) and adequate (40.4\%) the assistance they provide, and the actions conducted by the services where they work. Other findings regarding aspects related to health care provided are shown in Table 2.

Regarding the association between the dimensions of the $\mathrm{OMl}$ and academic and work data, associations were found in the dimension Authoritarianism with formation time $(p<0.01)$, weekly workload $(p<0.01)$, contact/experience with people with MD ( $p<0.01)$, health needs assessment conducted by the service where they work $(p<0.01)$ and type of formation institution ( $p<0.05)$, which express more negative attitudes, of authoritarian character by the professionals due to these work contexts.

The Benevolence dimension was associated with the variables formation time $(p<0.05)$, weekly workload $(p<0.01)$, frequency facing people with MD at work $(p<0.01)$ and evaluation of the assistance provided to the person with $M D(p<0.01)$, revealing more positive attitudes.

The Mental Hygiene Ideology dimension was associated with the weekly workload ( $p<0.05)$, mental health content/ discipline in formation $(p<0.05)$, contact/experience with people with $M D(p<0.01)$, which expresses more negative attitudes.
The Social Restriction dimension was associated with the weekly workload $(p<0.001)$, experience with people with MD $(p<0.05)$ evaluation of assistance to people with MD $(p<0.05)$, type of institution of private formation $(p<0.01)$, frequency with which they encounter people with $M D(p<0.05)$, also expresses negative attitudes within these specificities of work. In the Interpersonal Etiology dimension, with weekly workload ( $p<0.01)$, experience with people with MD $(p<0.01)$ and internship of mental health during formation $(p<0.05)$, revealing negative attitudes in this dimension (Table 3 ).

\section{DISCUSSION}

This study proposed to identify the attitudes of nurses working in $\mathrm{PHC}$ in relation to the person with $\mathrm{MD}$ and what are the variables that are related to these attitudes. The findings indicate that the global mean was higher than the cutoff point of the OMI scale, and the highlighted attitudes are Authoritarianism (44.6), Social Restriction (28.1) and Benevolence (51.7), allowing us to state that nurses' attitudes tend to be slightly more negative towards the person with $M D$, not recognizing them as subjects that are part of the general population.

According to the results obtained, the attitude of Authoritarianism, which characterizes the idea of irrecoverability and dangerousness, is negatively related to the time of formation. It can be inferred that the relatively short formation time, of a maximum of ten years, did not allow nurses in the present study to relational substrate to deal with people with MD, therefore, it tends to reject them, not recognizing them as the general population, despite their specific health needs. It should be noted, therefore, that changing attitudes in the face of any situation requires opportunity and time experience, which enables new learning and different postures ${ }^{(10-11)}$. 
Table 2 - Aspects related to health care provided to people with MD and the professional experience of nurses, study Attitudes in Primary Health Care, São Paulo, Brazil, 2019

\section{Variables}

\section{Care experience with people with MD}

No

Yes

Frequency you encounter with people with MD

Daily

Weekly

Monthly

Occasionally

Knowledge about health care needs to the person with MD

Very inadequate

Inadequate

Adequate

Very adequate

PHC $^{*}$ role in assistance in MD

Very inadequate

Inadequate

Adequate

Very adequate

Needs Assessment of care/health of people with MD

Very inadequate

Inadequate

Very adequate

Adequate

\section{Considers the assistance provided by the service}

Very inadequate

Inadequate

Very adequate 
Table 3 - Correlations to the OMI scale and variables of the study Attitudes in Primary Health Care, São Paulo, Brazil, 2019

\begin{tabular}{|c|c|c|c|c|c|}
\hline Variables & AUT & BEN & MHI & SR & IE \\
\hline Formation Time* & $0.001^{* *}$ & $0.013^{* *}$ & 0.091 & 0.380 & 0.615 \\
\hline Workload* & $0.002^{* *}$ & $0.002^{* *}$ & 0.395 & $0.000^{* *}$ & $0.002^{* *}$ \\
\hline Type of formation institution & $0.024^{* *}$ & 0.836 & 0.309 & $0.006^{* *}$ & 0.842 \\
\hline MH content/ discipline in formation & 0.864 & 0.312 & $0.038^{* *}$ & 0.632 & 0.109 \\
\hline $\mathrm{MH}^{*}$ internship in formation & 0.191 & 0.571 & 0.982 & 0.151 & $0.042^{* *}$ \\
\hline $\begin{array}{l}\text { Health needs assessment conducted by the } \\
\text { service where they work }\end{array}$ & 0.007 & 0.563 & 0.805 & 0.192 & 0.849 \\
\hline Contact/experience with people with MD & $0.001^{* *}$ & 0.209 & $0.006^{* *}$ & 0.037 & 0.008 \\
\hline Frequency of encounter people with MD & 0.222 & $0.007^{* *}$ & 0.862 & $0.026^{* *}$ & 0.144 \\
\hline Evaluation of assistance to people with MD & 0.808 & $0.001^{* *}$ & 0.601 & 0.011 & 0.118 \\
\hline
\end{tabular}

Source: Research data, 2019.

Notes: Spearman's correlation coefficient was used, ${ }^{* *}$ Significant correlation for $p<0.05 / \mathrm{MH}=$ Mental Health MD $=$ Mental Disorder

AUT=Authoritarianism, BEN= Benevolence, $\mathrm{MHI}=$ Mental Hygiene Ideology, $\mathrm{SR}=$ Social Restriction, IE= Interpersonal Etiology

The attitudes of Authoritarianism, Mental Hygiene Ideology, Social Restriction and Interpersonal Etiology also correlate with the weekly workload. Contextualizing the nurses' working conditions as part of the production of health services and changes in the way work is organized, it is observed that the demands on efficiency/productivity incorporate new personal and attitudinal elements, as well as accelerate and intensify the workload with a direct impact on the loss of professional autonomy ${ }^{(12)}$.

Thus, a study points out that FHS professionals ( $52 \%$ of the $\mathrm{BHU}$ in this study are with FHS), when sustaining their actions in the substantially biomedical model, justify this practice in the unpreparedness and impotence regarding the execution of care in $\mathrm{MH}^{(13)}$. It is assumed that these weaknesses have a direct impact on the autonomy and work process of nurses, with wear on the handling of the specific demands of this field. Furthermore, as they do not conceive the mental health-disease process under the perspective of psychosocial care, they tend to conduct a practice of care in $\mathrm{MH}$ in PHC that discredits the possibility of psychosocial rehabilitation, therefore, stigmatizing.

Having received content/discipline and an internship in $\mathrm{MH}$ during formation was negatively correlated with the dimensions Mental Hygiene Ideology and Interpersonal Etiology. This data represents a contradiction and opens space for discussion about the conducting of theoretical and practical nursing education in mental and psychiatric health in the reality of the city of São Paulo, and even Brazilian, with regard to the curricular references adopted in the teaching-learning process and its articulation with the guidelines of the National Mental Health Policy.

Once the biopsychosocial aspects of health care are advocated, the theoretical/practical framework and the pedagogical assumptions used in the formation must support the construction of specific competences in the area of $\mathrm{MH}$ that consolidate the professional profile, as well as positive attitudes according to principles of Psychiatric Reform.

Research points out that the total hours dedicated to the discipline in mental/psychiatric health is still insufficient when compared to the other specialties that make up the curriculum of undergraduate nursing courses ${ }^{(14)}$. $\mathrm{MH}$ is a forgotten area and little valued by society, so it also seems to be in second plan in the area of education.

Nevertheless, the theoretical content alone is not enough, and practical experiences are relevant, since changing attitudes towards a given situation implies a period of experience until new attitudes are incorporated into the personality ${ }^{(15)}$. Anyway, the greater the theoretical/practical quantity during formation, the more positive tend to be professional attitudes $^{(16)}$. 
Dealing with the mental health demands of users/family and not having the formation structure to develop $\mathrm{MH}$ actions are limitations that are consistent with unfriendly attitudes. For the nurses in this study, the contact/experience with people with MD showed a positive correlation in relation to having Authoritarianism attitudes and Mental Hygiene Ideology, that is, the more contact/experience they had, the more the attitudes were negative. This finding contrasts with the literature, which shows that greater contact/relational experience provides more positive attitudes ${ }^{(17)}$. It is argued that this result is due to the way of teaching, the internship fields used, and the theoretical framework approached in the discipline.

The assessment of health needs and the planning of care for the person with MD may be related to the nurses' understanding of the mental health-illness process. It is from this conception that they appropriate the object of care. Thus, the Authoritarianism dimension is negatively correlated with the nurses' perspective on how the BHUs conduct the assessment of health needs. It is assumed that this attitude can be sustained in the academic formation still rooted in the asylum model that feeds authoritarian attitudes, although contradictions are observed since nurses exercise benevolence.

This fact makes it possible to criticize the way in which the assessment of assistance is carried out, considering that their opinion about this action is broad, since it considers it very inadequate $(24.0 \%)$, very adequate $(27.6 \%)$, adequate (33.6\%), and inadequate (14.8\%). Likewise, the opinion on the conduct of assistance to people with MD provided by their services is very inadequate (13.2\%), very adequate (31.6\%), adequate (40.4\%), and inadequate (14.8\%). Despite the discrepancy of opinions, there is unanimity in the questions "assessment and conduct of assistance", seen as inadequate.

The type of Higher Education Institution (HEI) where the nurses did their graduation is mostly private and correlates with the attitude of Authoritarianism and Social Restriction. These HEls have provided a considerable number of nurses in the world of work, with an emphasis on the Southeast region, who must be able to answer the health singularities and social demands of the population ${ }^{(18)}$. In order to produce in nurses more positive attitudes towards the person with $M D$, it is essential that these professionals allow themselves to strengthen contact with this population; invest in proximity to professionals/specialized services to enrich the framework that supports $\mathrm{MH}$ actions in this scenario, as well as being supported by technical knowledge.
Benevolent attitudes, when elevated, demonstrate that nurses have a lesser tendency to exercise authoritarian attitudes and restrict freedom to people with MD, and puts them in a position to support them through care, personal attention and comfort ${ }^{(19)}$. Although the nurses in this study had little time since graduating (five to ten years), and this time was correlated with the attitude of Authoritarianism, the nurses continued to exercise the attitude of Benevolence. Even so, it is emphasized that nurses can make an interpretation based on excludent models, widely postulated throughout the history of madness.

The workload also implies an attitude of Benevolence. Considering that the PHC/FHS nurses deal intensively with the population of the assigned territory ${ }^{(20)}$, and, even though they do not deeply recognize their needs for $\mathrm{MH}$, they live daily with the specificities of their demands and this process can constitute skills and knowledge that will support $\mathrm{MH}$ actions.

Even so, it is worth noting that even with a more positive attitudinal profile for Benevolence, there is a need for investments and training, given that due to challenges of PSCN materialization, the scenario requires nurses prepared to deal with mental health demands.

Despite being benevolent, the nurses in this study are not aware of the health needs of this population. Such findings corroborate research developed in South Africa, through an observational study with primary health care nurses, which detected their difficulty in managing mental health care in the community ${ }^{(6)}$. In view of this, the chances of nurses in the present study to conduct fragile care, and to exercise authoritarian and social exclusion attitudes, increase because they are unable to absorb the demands of this clientele.

The frequency and experience of care that nurses in this study have with people with MD in their work spaces in PHC (63.6\%) may be reflex of the historical, political and social process of transforming mental health care, with a view to to realize the right to comprehensive health care in the community in non-specialized spaces. However, the materialization of this process will be possible if these professionals add in their care practices new meanings and new perspectives on this population.

As this is a cross-sectional study and convenience sample, the limitations are related to the fact that the results suffer temporal bias and are not representative of other populations, due to the specificity of the one studied. Therefore, other studies are recommended in order to establish factors that provide positive or negative attitudes and actions taken to strengthen or deconstruct them. 


\section{Q CONCLUSIONS}

The inclusion of mental health in PHC has been one of the greatest challenges facing health systems worldwide. In order to face them, the qualification of those who are at the forefront of care in this field, namely nurses, is essential.

Since the attitudinal profile of the nurses in the present study is mostly more negative towards the person with MD, although there is a positive benevolent attitudinal perspective in parallel, it is demonstrated need for formative and permanent intervention that allows greater responsibility, awareness and professional leadership to maintain protective behavior towards the person with MD without however, underestimating their abilities.

The short formation time (average of ten years) and the weekly workload of 40 hours a week lead to an attitude that is both negative and positive. The variables that lead to negative attitudes by nurses reflect on the contact/ experience they have with people with MD, on the way of assessing the health needs conducted in the services where they work, which may disfavor the conduct of more structured actions and produce wear in the care process. Another variable involves the type of formation institution, which is predominantly private.

The frequent contact and the assessment of the assistance that is provided in primary care favor more positive attitudes and indicate that the approach of nurses to this clientele and their health needs, as long as it is supported by technical and scientific knowledge, can induce care practices in mental health in PHC more inclusive and of co-responsibility in the context of teamwork in PSCN.

It is also noteworthy that despite having received content/discipline and clinical practice in $\mathrm{MH}$ in formation, nurses have negative attitudes, particularly from Interpersonal Etiology and Mental Hygiene Ideology. This reveals that the teaching logic is still based on the explanation of MD origins only in interpersonal and parenting experiences, without considering social interactions.

Evaluating attitudes makes it possible to understand the quantitative or qualitative differences that the person with MD presents, but it is emphasized that nurses must stick to this duality, since fragmenting quanti/qualitative the person, will compromise the care in its totality.

\section{REFERENCES}

1. Barros S, Nóbrega MPSS, Santos JC, Fonseca LM, Floriano LSM. Saúde mental na atenção primária: processo saúde-doença, segundo profissionais de saúde. Rev. Bras. Enferm. 2019; 72(6): 1609-1617 doi: https://doi. org/10.1590/0034-7167-2018-0743.
2. Vala J, Monteiro MB. Psicologia social. ga ed. Lisboa: Fundação Calouste Gulbenkian; 2013.

3. Abramenko L, Lovisi GM, Fonseca DL, Abelha L. Atitudes dos trabalhadores de saúde mental em relação aos pacientes psiquiátricos em uma cidade do interior do Estado do Rio de Janeiro. Cad Saúde Colet. 2017;25(2) 169-76. doi: https:// doi.org/10.1590/1414-462×2017000200019

4. Siqueira SR, Abelha L, Lovisi GM, Sarução KR, Yang L. Attitudes Towards the Mentally III: A Studywith Health Workersat a University Hospital in Rio de Janeiro. Psychiatr Q. 2017 Mar;88(1):25-38. doi: https://doi.org/10.1007/ s11126-016-9431-5

5. Chambers ML, Guise V. Välimäki M, Botelho MA. Scott A. Staniuliené V, Zanotti R. Nurses' attitudes to mental illness: a comparison of a sample of nurses from five European countries. Int J Nurs Stud. 2010;47(3):350-62. doi: https://doi. org/10.1016/j.jpurstu.2009.08.008

6. Dube, FN, Uys, L. R. Integrating mental health care services in primary health care clinics: a survey of primary health care nurses' knowledge, attitudes and beliefs. South African Family Practice. 2016;58(3):119-25. doi: https://doi.org /10.1080/20786190.2016.1191747

7. Ma Z, Huang H, Nie G, Silenzio VMB, Wei B. Attitudes towards mental illness among primary healthcare providers: a community-based study in rural China. BioMed Res Int. 2018;8715272. doi: https://doi.org/10.1155/2018/8715272

8. Gonçalves AM, Vilela SC, Terra FS, Nogueira DA. Attitudes and pleasure/suffering in mental health work. Rev Bras Enferm. 2016;69(2):266-74. doi: https://doi. org/10.1590/0034-7167.2016690209i

9. Rodrigues, CRC. Atitudes frente a doença mental: estudo transversal de uma amostra de profissionais da saúde [tese]. Ribeirão Preto (SP): Faculdade de Medicina de Ribeirão Preto, USP; 1983.

10. Romano AMM, Pedrão LJ, Costa Junior ML, Miasso Al. The impact of academic training on authoritarianism displayed by nursing students towards mental illness. Rev Enferm UFPE On Line. 2014 [cited 2019 Dec 15];8(6):1545-52. Available from: https://periodicos.ufpe.br/revistas/revistaenfermagem/article/ view/9844/10050

11. Matsumura ESS, França AS, Alves LMF, Silveira MKS, Sousa Júnior AS, Cunha KC. Spacial distribution of nursing graduate courses. Rev Enferm UFPE On Line. 2018 [cited 2019 Dec 15];12(12):3271-78. Available from: https://periodicos.ufpe. br/revistas/revistaenfermagem/article/view/236270/30855

12. Souza EA, Teixeira CF, Souza MKB. Análise da produção científica nacional sobre 0 trabalho da enfermeira (1988-2014). Saúde Debate. 2017;41(113):630-46. doi: https://doi.org/10.1590/0103-1104201711322

13. Rotoli A, Silva MRS, Santos AM, Oliveira AMN, Gomes GC. Mental health in Primary Care: challenges for the resoluteness of actions. Esc Anna Nery. 2019;23(2):20180303. doi: https://doi. org/10.1590/2177-9465-ean-2018-0303

14. Vargas D, Maciel MED, Bittencourt MN, Lenate JS, Pereira CF. Teaching psychiatric and mental health nursing in Brazil: curricular analysis of the undergraduation course. Texto Contexto Enferm. 2018;27(2):261-70. doi: https://doi. org/10.1590/0104-070720180002610016

15. Happell B, Gaskin (J. The attitudes of undergraduate nursing students to wards mental health nursing: a systematic review. J Clin Nurs. 2013 Jan; 22(1-2):14858. doi: https://doi.org/10.1111/jocn.12022

16. Eack SM, Newhill CE. An investigation of the relations between student knowledge, personal contact and attitudes toward individuals with schizophrenia. J Soc Work Educ. 2008:44(3):77-96. doi: https://doi. org/10.5175/JSWE.2008.200700009 
17. Santos SS, Soares MH, Hirata AGP. Attitudes, knowledge, and opinions regarding mental health among undergraduate nursing students. Rev Esc Enferm USP. 2013;47(5):1202-10. doi: https://doi.org/10.1590/ S0080-623420130000500026

18. Frota MA, Wermelinger MMW, Vieira LJES, Ximenes NFRG, Queiroz RSM, Amorim RF. Mapping nursing training in Brazil: challenges for actions in complex and globalized scenarios. Ciênc Saúde Coletiva. 2020;25(1):25-35. doi: https://doi.org/10.1590/1413-81232020251.27672019

19. Fernandes CSNN, Santos WBC, Moreira WC, Vargas D, Nóbrega MPSS. Opinions on mental illness from the perspective of primary care nurses in Portugal. Rev Gaúcha Enferm. 2019;40:e20190034. doi: https://doi. org/10.1590/1983-1447.2019.20190034

\section{- Corresponding author:}

Maria do Perpétuo Socorro de Sousa Nóbrega

Email: perpetua.nobrega@usp.br
20. Lima EFA, Sousa Al, Leite FMC, Lima RCD, Souza MHN, Primo CC. Evaluation of the Family Healthcare Strategy from the perspective of health professionals. Esc Anna Nery. 2016 [cited 2019 Dec 15];20(2):275-80. Available from: https:// www.scielo.br/pdf/ean/v20n2/en_1414-8145-ean-20-02-0275.pdf

\section{Funding/Acknowledgment:}

Coordination for the Improvement of Higher Education Personnel (Coordenação de Aperfeiçoamento de Pessoal de Nivel Superior - (APES) Program of Visiting Professor Abroad - Public Notice 9/2019 Print USP-Portugal (Scholarship). Work developed in the Postgraduate Program in Nursing - School of Nursing of the Universidade de São Paulo (EEUSP).
Associate editor:

Rosana Maffacciolli

\section{Editor-in-chief:}

Maria da Graça Oliveira Crossetti 